\title{
Histopathology of the renal and splenic haemopoietic tissues of coho salmon Oncorhynchus kisutch experimentally infected with Renibacterium salmoninarum
}

\author{
E. Flaño ${ }^{1}$, P. López-Fierro ${ }^{1}$, B. Razquin ${ }^{1}$, S. L. Kaattari ${ }^{2}$, A. Villena ${ }^{1, *}$ \\ 'Departamento de Biología Celular y Anatomía, Facultad de Biología, Universidad de León, E-24071 León, Spain \\ ${ }^{2}$ Virginia Institute of Marine Science, College of William \& Mary, Gloucester Point, Virginia 23062-1346, USA
}

\begin{abstract}
We report the histopathological changes occurring in the renal and splenic haemopoietic tissues of coho salmon Oncorhynchus kisutch experimentally infected with Renibacterium salmoninarum. In both tissues we were able by light microscopy to distinguish 3 different grades in the progression of the infection. The grades of infection were characterized according to the location of the bacteria and the tissue injuries. Ultrastructural observation revealed sinusoidal cells, macrophages, reticular and barrier cells to be infected by the pathogen, and necrosis of the tissue to be general in advanced stages of the infection. Despite destruction of the haemopoietic tissue, plasmacytopoietic foci were frequently observed in both organs. Other major changes were the appearance of epithelioid cells and an increase in the number of barrier cells. These 2 cell types might be involved in the local defence response to the pathogen, but they may also act as a reservoir and proliferation locus for R. salmoninarum.
\end{abstract}

KEY WORDS: BKD - Renibacterium salmoninarum - Histopathology - Haemopoietic tissue - Kidney Spleen · Oncorhynchus kisutch · Fish

\section{INTRODUCTION}

Bacterial kidney disease (BKD) is a chronic systemic infection caused by the Gram-positive bacterium Renibacterium salmoninarum (Sanders \& Fryer 1980, Fryer \& Sanders 1981, Evenden et al. 1993), characterized by a granulomatous inflammatory response (Wolke 1975) and marked affinity for kidney tissue (Belding \& Merril 1935, Earp et al. 1953).

The disease causes anaemia (Bruno 1986) and destruction of the haemopoietic tissue (Wood \& Yasutake 1956). Histopathological changes in several tissues of fish naturally and experimentally infected with Renibacterium salmoninarum have been described (Wood \& Yasutake 1956, Young \& Chapman 1978, Bruno 1986, Sami et al. 1992, Evenden et al. 1993). Few de-

\footnotetext{
•Addressee for correspondence. E-mail: villena@ibm.net
}

scriptions exist, however, of the ultrastructural pathology associated with infection of lymphohaemopoietic tissue. In this paper, we describe the changes observed in the kidney and spleen of coho salmon Oncorhynchus kisutch experimentally infected with $R$. salmoninarum, with special reference to the ultrastructure of the cell types forming the haemopoietic microenvironment.

\section{MATERIALS AND METHODS}

Specimens. Fingerling coho salmon Oncorhynchus kisutch ( 6 to $8 \mathrm{~cm}$ in length) were kept in $1 \mathrm{~m}^{3}$ circular tanks supplied with $12^{\circ} \mathrm{C}$ pathogen-free well water under natural photoperiod conditions at the Oregon State University Salmon Disease Laboratory (Corvallis, OR, USA). They were fed daily with Oregon Moist Pellets (Bioproducts, Warrington, OR). 
Experimental infection. Infections were performed in 1301 tanks supplied from the above water source Thirty fish were intraperitoneally (i.p.) injected with a single dose of $0.1 \mathrm{ml}\left(10^{7}\right.$ cells) viable Renibacterium salmoninarum (D6 isolate, provided by C. Banner, Oregon Department of Fish and Wildlife, Oregon, USA) in saline solution. Ten non-infected salmon, i.p. injected with $0.1 \mathrm{ml}$ of saline solution, were used as controls.

Histological techniques. For the electron microscopy study, samples were taken weekly from 1 to 7 wk post-infection. Each time, 3 infected fish and 1 control were euthanized by anaesthetic overdose using a $200 \mathrm{mg} \mathrm{l}^{-1}$ solution of MS-222 (Sandoz). The fish were then bled by severing the tail, and the kidney (pronephros and mesonephros) and spleen were aseptically remnved Small pieces of these organs worc fixed for $4 \mathrm{~h}$ in $2 \%$ glutaraldehyde in cacodylate buffer, $0.2 \mathrm{M}, \mathrm{pH} 7.2$, at $4^{\circ} \mathrm{C}$. Tissues were then postfixed for $1 \mathrm{~h}$ in $1 \%$ osmium tetroxide in the same buffer at $4^{\circ} \mathrm{C}$, dehydrated in acetone and embedded in Araldite (Durcupan). Semithin (1 $\mu \mathrm{m}$ thick) and ultrathin sections were cut on a Reichert UM-3 ultratome with glass knives. The semithin sections were stained with a $1 \%$ aqueous solution of toluidine blue in borax. The ultrathin sections were transferred to copper grids, double-stained with uranyl acetate and lead citrate (Reynolds 1963) and observed in a Jeol-100C electron microscope at $80 \mathrm{kV}$.

\section{RESULTS}

\section{Kidney}

By light microscopy, we were able to distinguish 3 grades in the progression of the infection in this organ, according to the location of the bacteria and tissue injury. At short periods post-infection ( 1 to $3 \mathrm{wk}$ ) focal infected areas were observed, and there was a correiation between the time post-infection and the grade of infection. However, after $4 \mathrm{wk}$ post-infection, tissue damage became extensive, and several grades of infection were observed simultaneously in different zones of the same organ. The grades of infection were characterized as follows:

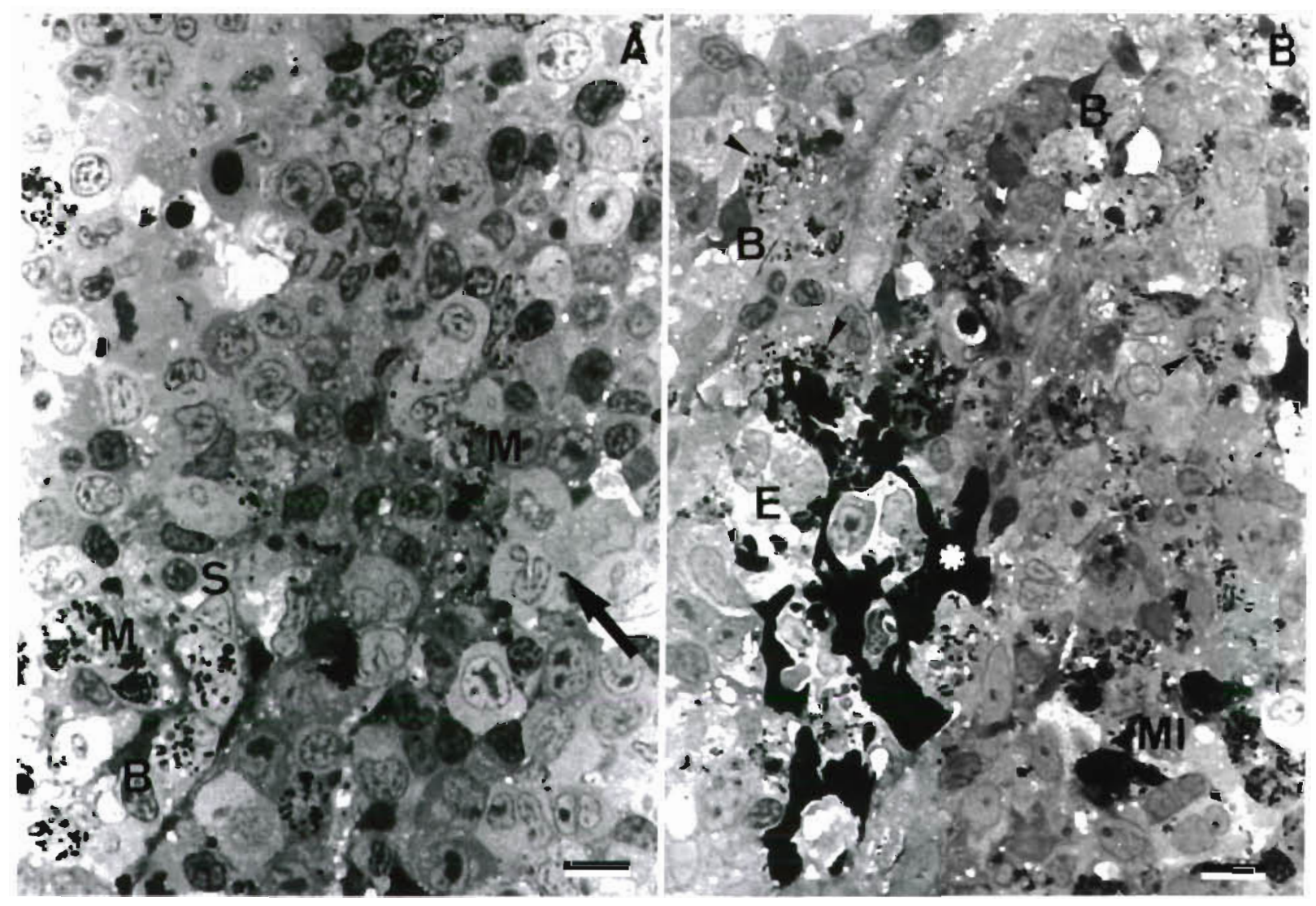

Fig. 1. Histopathology of the haemopoietic tissue of the kidney in Renibacterium salmoninarum-infected coho salmon Oncorhynchus kisutch. (A) Pronephros with the histopathological characteristics of grade 2 infection, at 7 wk post-infection. Note the presence of monocyte-like cells (arrow), an infected sinusoidal cell (S), infected macrophages (M) and a barrier cell (B). (B) Mesonephros, at 7 wk post-infection, showing the histopathological changes of grade 3 of infection. Note the presence of tibrin clumps (asterisk) and epithelioid cells (E), bacteria (arrowhead), barrier cells (B), and melanomacrophages (MI). Semithin sections. Scale bars $=10 \mu m$ 
Grade 1: Circulating bacteria were observed in the lumina of blood sinusoids, and a low number of bacteria located in the cytoplasm of sinusoidal-lining cells, some of which appeared hypertrophic, but no other tissue alterations were evident.

Grade 2: This stage was characterized by entry of the pathogen into the lymphohaemopoietic parenchyma, and focal tissue damage. A great many bacteria invaded the parenchyma, locating especially in macrophages (Fig. 1A) but also in the cytoplasm of the sinusoidal-lining cells (Fig. 1A). Monocyte-like cells, with a euchromatic nucleus and a slightly stained cytoplasm, and pyknotic cells, some of them engulfed in macrophages and melanomacrophages, were present in large numbers in the parenchyma. There were heavily stained barrier cells with elongated and branched cytoplasm (Fig. 1A), which morphologically resembled the barrier cells of the mammalian lymphoid and haemopoietic tissues (Weiss 1991, Weiss \& Geduldig 1991).

Grade 3: In this last stage, lysis of the infected cells with extracellular dispersion of the bacteria throughout the tissue was evident (Fig. 1B). Large areas of the renal tissue became necrotic, and melanin granules were disseminated throughout it. Fibrin clumps (Fig. 1B) also appeared in these areas. An increase in the number of monocyte-like and barrier cells was apparent. The progression of the infection was associated with a concomitant decrease in the number of erythrocytes.

Through the different grades of infection, ultrastructural changes were observed in most of the cell types of the renal haemopoietic tissue. Infected sinusoidal-lining cells showed hypertrophy and degenerative changes of the cytoplasm (Fig. 2A). The reticular cells showed little alteration through infection grades 1 and 2. In the infected necrotic areas, however, some of the few reticular cells observed contained bacteria in the cytoplasm, and appeared degenerated (Fig. 2B). Melanomacrophages, which accumulated in the necrotic tissues, also appeared infected by bacteria (Fig. 2C).

The epithelioid cells present in the infected tissue had monocyte-like features, being round with a euchromatic bilobulated or indented nucleus and a low electron-dense cytoplasm (Fig. 3B, C). Major cytoplasmic organelles were a prominent Golgi apparatus, numerous moderate electron-dense small vesicles and lysosome-like bodies. In some cases, these cells formed clusters and some of them contained bacteria in the cytoplasm (Fig. 3C).

Barrier cells, present in large numbers in grade 2 and 3 infections, were ultrastructurally characterized by a high nuclear and cytoplasmic electron density, and stellate morphology (Fig. 3A, B). They were located lining the basal pole of degenerating sinusoidal-lining cells (Figs. 1A \& $3 \mathrm{~A}$ ) and bordering the necrotic tissue areas. Barrier cells often appeared fused together in syncytial networks (Fig. 3B). Some barrier cells showed a high phagocytic activity, appearing full of bacteria (Fig. 3C).

Apart from the above-cited cell types, the renal lymphohaemopoietic tissue of infected coho salmon was severely depleted of other leukocytes and erythrocytes (Fig. 1B). Although a low number of lymphoid cells were present, plasmacytopoietic foci were frequently observed (Fig. 3D). No granulocytes or lymphocytes with intracellular bacteria were ever observed.

\section{Spleen}

Three grades of progression of the infection in the spleen, with histopathological features resembling those described for the renal lymphohaemopoietic tissue, were also noted. At 2 wk post-infection, the grade 1 infection was characterized by the presence of moderate to high numbers of bacteria located in the sinusoidal lumina and inside the sinusoidal-lining cells (Fig. 4A). Grade 2 of infection was characterized by the entry of bacteria into the splenic parenchyma. Focally infected areas of tissue contained bacteria, epithelioid cells and a low number of erythrocytes (Fig. 4B). In grade 3 of infection, the infected tissue showed necrosis with intra- and extracellular bacteria, pyknotic cells and fibrin clumps, and there was evident depletion of leukocytes and erythrocytes. During grade 1 and 2 infections, melanomacrophages and barrier cells were less noticeable than in the renal lymphohaemopoietic tissue.

The ultrastructural changes observed in the reticular, barrier and sinusoidal-lining cells and melanomacrophages were similar to those described in the kidney. In the last stage of the infection, macrophages and barrier cells were full of bacteria (Fig. 5A, B). There was a remarkable depletion of granulocytes and lymphocytes, but some plasmacytopoietic foci were observed (Fig. 5D).

Although bacteria were present in arterioles (Fig. 4B) and in the sinusoids (Fig. 4A), there were none in the ellipsoids (Fig. 5C), even in heavily invaded tissue areas.

\section{DISCUSSION}

Events in the early stages of the experimental infection of coho salmon with Renibacterium salmoninarum reported here, where the kidney is the first organ infected at 2 wk post-infection, are in accordance with early reports in which $\mathrm{BKD}$ was defined as a systemic 

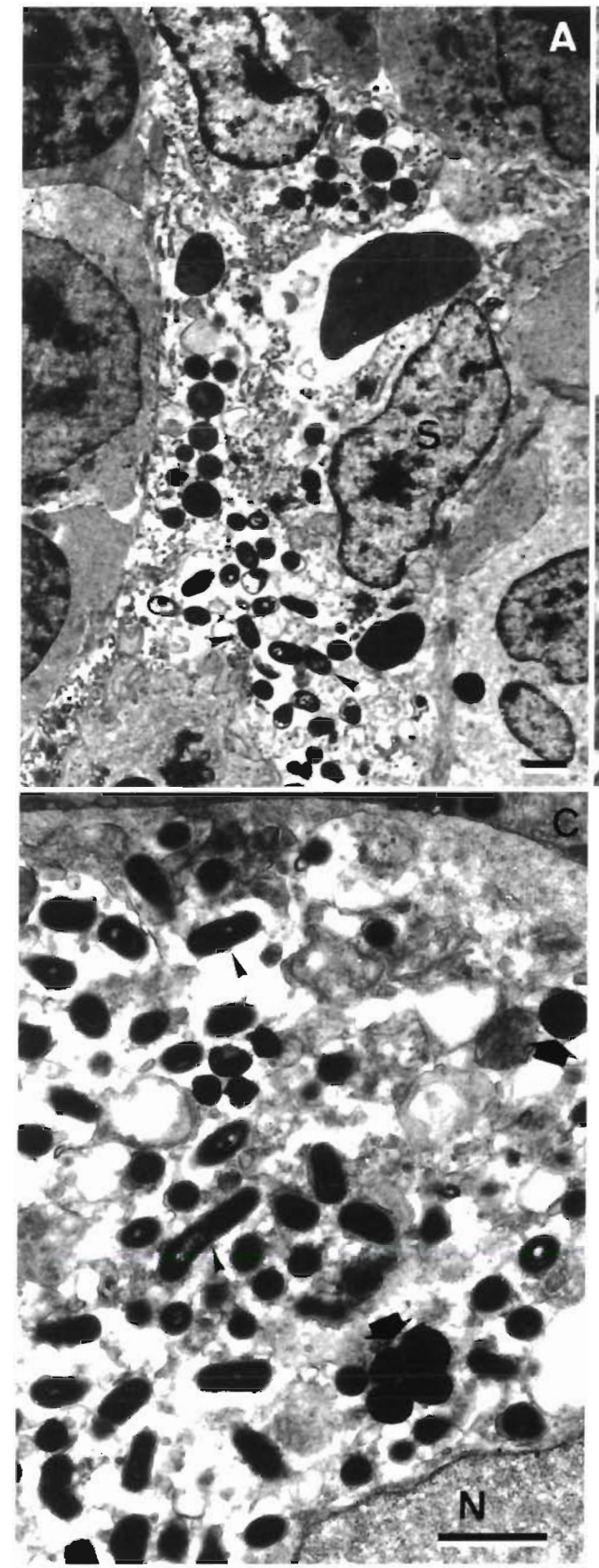

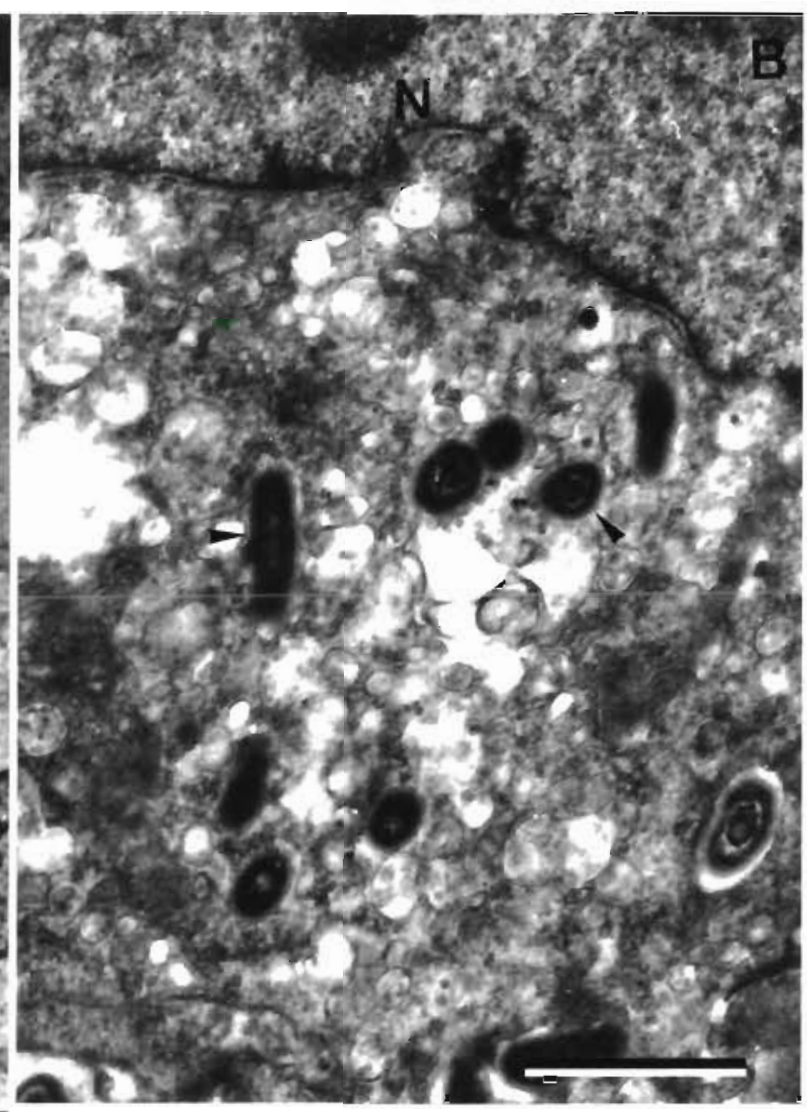

$\Delta$

Fig. 2. Ultrastructure of the haemopoietic tissue of the mesonephros of a Renibacterium salmoninaruminfected coho salmon Oncorhynchus kisutch at $7 \mathrm{wk}$ post-infection. (A) Blood sinusoid, with a degenerated sinusoidal cell (S) with bacteria (arrowhead) (B) Reticular cell showing cytoplasmic bacteria (arrowhead). (C) Bacteria (arrowhead) and melanin granules (large arrow) in the cytoplasm of a melanomacrophage. $N$ : nucleus. Scale bars $=1 \mu \mathrm{m}$

Fig 3. Ultrastructural features of the haemopoietic tissue of the kidney in Renibacterium salmoninarum. infected coho salmon Oncorhynchus kisutch. (A) A typical barrier cell is shown. Its cell processes extend between a degenerated sinusoidal cell (S), a lymphocyte (L). and a plasma cell (P). Pronephros at $2 \mathrm{wk}$ post-infection. (B) Network of barrier cells (B) among epithelioid cells (E). Mesonephros at 2 wk post-infection. (C) Epithelioid (E) and barrier cells (B) containing numerous cytoplasmic bacteria. Mesonephros at 7 wk post-infection. (D) Plasmacytopoietic foci in a degenerate area. Plasma cells (P), degenerate epithelioid cells (E), and melanin granules (large arrows). Pronephros at 7 wk post-infection. Scale bars $=1 \mu \mathrm{m}$ 

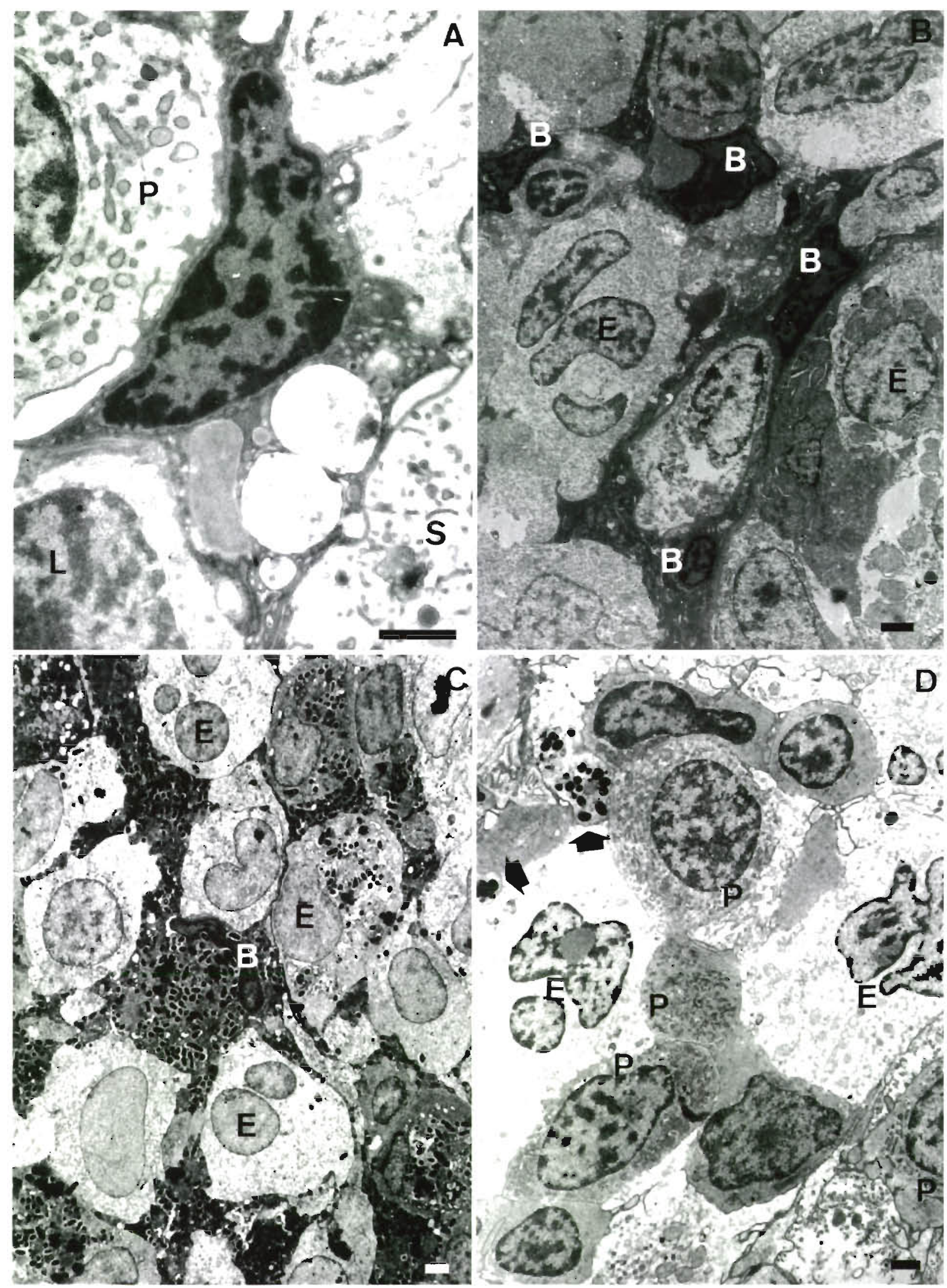


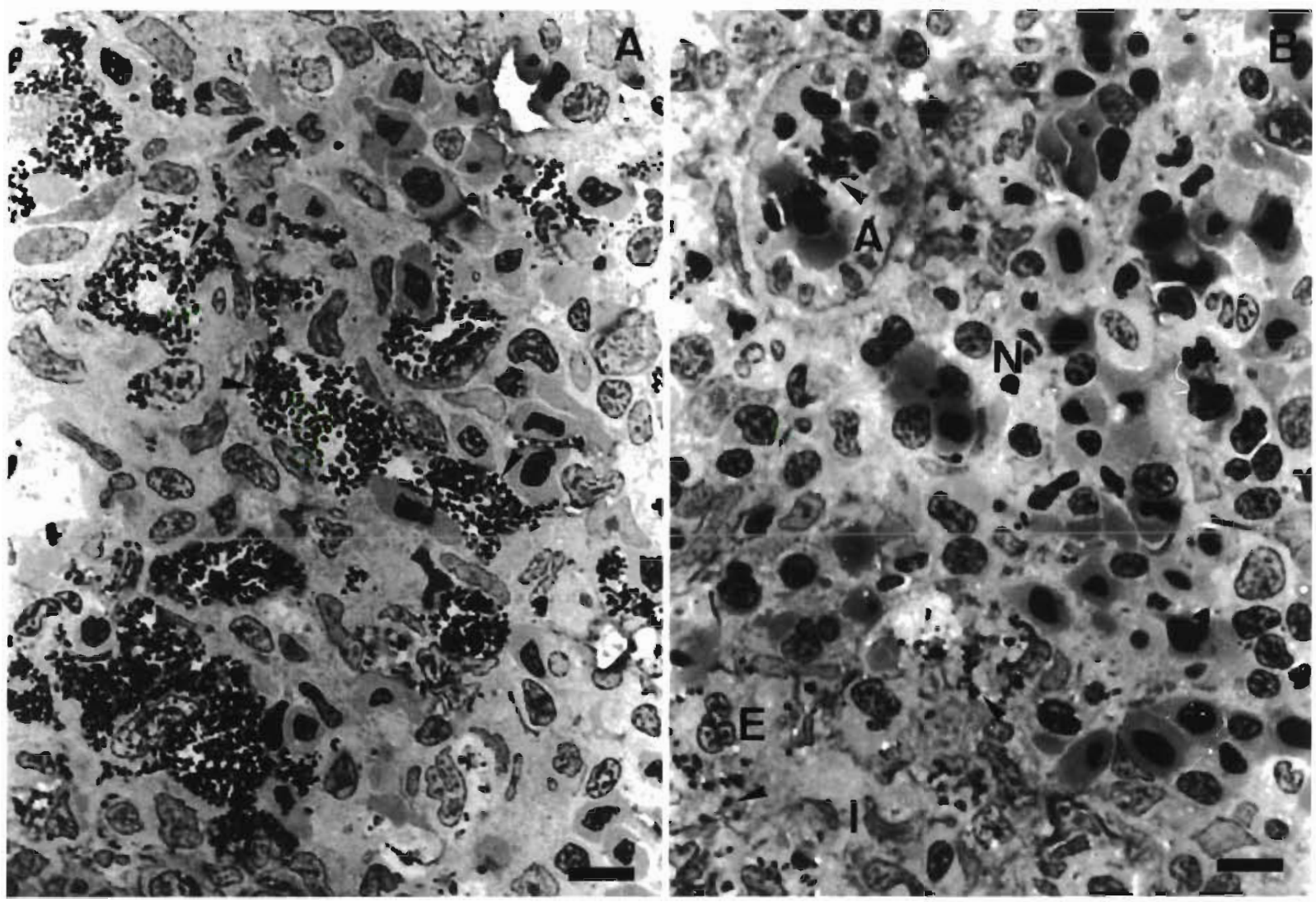

Fig. 4. Histopathology of the spleen in Renibacterium salmoninarum-infected coho salmon Oncorhynchus kisutch. (A) Infected area showing the histopathological changes of grade 1 of infection at 2 wk post-infection. Arrowhead: numerous bacteria located in the blood sinusoids. (B) Note the clear demarcation between an infected area (I) showing the histopathological features of grade 2 of infection at 6 wh post-infection with bacteria (arrowhead) and epithelioid cells (E), and a non-infected area (N) with an arteriole (A) containing circulating bacteria (arrowhead). Semithin sections. Scale bars $=10 \mu \mathrm{m}$

infection with a pronounced affinity for the kidney (Sniezsko \& Griffin 1955, Wood \& Yasutake 1956). In our results, free $R$. salmoninarum appeared initially in the lumina of different blood vessels and in the lining cells of the blood sinusoids, with the bacteria later invading the cell cords of the renal lymphohaemopoietic tissue and the spleen. These results show that $R$. salmoninarum may progress, in the early stages, via systemic infection (Wood \& Yasutake 1956, Young \& Chapman 1978). In our experimental model, infection of the lymphohaemopoietic organs was initially caused by circulating bacteria, and not via phagocytic cells. However, the ellipsoids, a specific component of the splenic circulation, were free of bacteria even in the most advanced stages of the infection, in contrast with a previous report by Bruno (1986) in which bacteria appeared in the phagocytic cells associated with the ellipsoids and within the reticulin sheaths of these blood vessels.

During the infection, the histopathological changes in the renal and splenic tissues were similar, and we classified them in 3 grades. In grade 1 , bacteria were observed free in blood vessels and engulfed in the cytoplasm of sinusoidal-lining cells, with no other signs of pathological changes in the tissues. The lesions in grade 2 were characterized by the invasion of the parenchyma by bacteria; the invasion was accompanied by changes in the tissues, involving the appear-

Fig. 5. Ultrastructural aspect of the splenic tissue in Renibacterium salmoninarum-infected coho salmon Oncorhynchus kisutch. (A) Red pulp area at 7 wk post-infection showing barrier cells (B), an infected macrophage (M), a lymphocyte (L) and epithelioid cells (E). (B) White pulp area at 7 wk post-infection with a cluster of phagocytic barrier cells containing bacteria (arrowhead). (C) Ellipsoid in an infected area, with bacteria (arrowhead) located in the lumen of the surrounding sinusoid, and a degenerated sinusoidal cell (S). Ed: Ellipsoidal endothelial cells; P: periellipsoidal cells. Spleen at 2 wk post-infection. (D) Plasmacytopoietic foci at $7 \mathrm{wk}$ post-infection. Arrowheads: bacteria. Scale bars $=1 \mu \mathrm{m}$ 


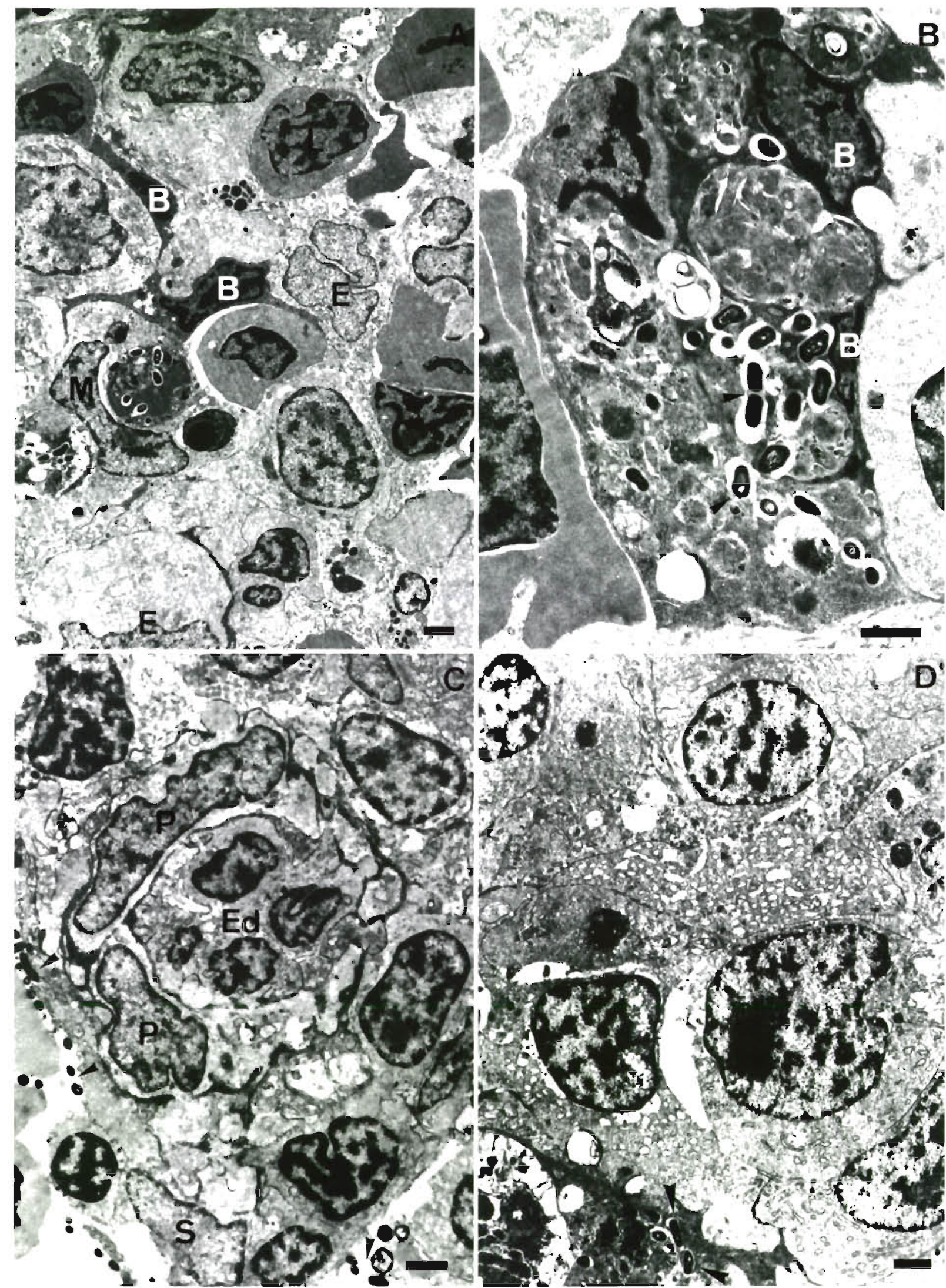


ance of epithelioid cells and an increase in the number of barrier cells, melanomacrophages and pyknotic cells. In grade 3 , features common to the kidney and spleen were the extracellular dispersion of the bacteria, caused by the lysis of infected cells, and necrosis of the tissue. Our system of grading the tissue changes accurately reflected the chronology of the 'tissue events' during the early infective stages. However, from the 3rd wk post-infection, there was no correlation between the grade of tissue injury and the post-infection time. Thereafter, different grades of lesion occurred in the same organ, but in separate areas, reflecting the fact that Renibacterium salmoninarum causes focal necrosis (Wood \& Yasutake 1956, Smith 1964).

From the grade 2 infection stage onwards, the reticular and sinusoidal-lining cells, which form part of the haemopoietic microenvironments of the pronephric and splenic tissues (Zapata 1979, 1982, Razquin et al. 1990), underwent considerable changes. The reticular cells, which were only rarely observed to contain bacteria, decreased in numbers. The sinusoidal-lining cells proved actively phagocytic, in agreement with the reports of Álvarez et al. (1988) and Dannevig et al. (1994) for other salmonids, and were the earliest cells to contain intracytoplasmic bacteria (probably owing to the fact that they form the first physical barrier to circulating bacteria in both organs). The ingestion of the pathogen by the sinusoidal-lining cells may represent a step favouring the pathogen because it is reported as capable of replicating intracellularly, for example, in macrophages (Bandín et al. 1993). After this, lysis of infected sinusoidal-lining cells resulted in the release of the accumulated cytoplasmic bacteria, thus contributing to bacterial colonization of the parenchyma and to the ultimate destruction of cells in much of the haemopoietic microenvironment. The destruction of cells of the haemopoietic microenvironment probably accounts for the hypoplastic anaemia common in BKD, and likely explains the erythropenia associated with the disease.

In Renibacterium salmoninarum-infected fish, the renal and splenic haemopoietic tissues were colonized by epithelioid cells, some of which might fuse to form giant multinucleated cells in the most advanced stages of infection. The presence of giant cells was previously demonstrated by Sniezsko \& Griffin (1955) and Wood \& Yasutake (1956) in natural infections with $R$. salmoninarum, although they have not been described in later histopathological studies (Smith 1964, Young \& Chapman 1978, Bruno 1986, Hayakawa et al. 1989). The development of these cells might be related to a subacute course of the infection, either due to the dose and route of inoculation, or to the characteristics of specific isolates of $R$. salmoninarum. Although the epithelioid cells showed no marked phagocytic activity, on the basis of their nuclear morphology, and cytoplasmic organelles, we think that they probably differentiate from monocytes/macrophages, as has been previously described in fish (Richards et al. 1978, Secombes 1985) and in mammals (Papadimitriou \& Van Bruggen 1986 Kreipe et al. 1988). An increase in the number of circulating monocytic cells (Bruno \& Munro 1986) and of phagocytic cells in the kidney has been observed in rainbow trout and Atlantic salmon experimentally infected with $R$. salmoninarum (Bruno 1986).

Melanomacrophages were involved in the histopathological changes after the experimental infection with Renibacterium salmoninarum. In the early stages, these located around infected tissue areas, showing a high phagocytic activity, containing cell debris and seemingly unaltered bacteria. Some bacteria appear to be able to divide in the cytoplasm of melanomacrophages and, therefore, these cells may serve as a site for active proliferation of the bacteria, as described for macrophages (Young \& Chapman 1978, Bandín et al 1993). The lysis of the infected melanomacrophages may be the origin of the dispersed melanin in the tissues, a histopathological characteristic of BKD (Bruno 1986).

A remarkable finding in our results was the increased number of barrier cells in the renal and splenic haemopoietic tissues of infected fish. The structure and putative role of mammalian barrier cells have been reviewed by Weiss (1991). We have described the presence of reticular-like cells morphologically resembling barrier cells in other salmonids (Castillo 1991, Álvarez 1993, Álvarez et al. 1993), and their structural features also coincide with those reported here. In the kidney and spleen, the barrier cells formed meshworks lining infected and necrotic areas, and some of them contained abundant cellular debris, residual bodies and bacteria in their cytoplasm. Therefore, barrier cells may play an important role in the defense against Renibacterium salmoninarum, and probably against other microbial infections in fish, as has been described in mammals (Weiss 1991, Weiss \& Geduldig 1991). On the other hand, barrier cells contained numerous apparently undamaged bacteria and, therefore, they might constitute a reservoir and a proliferation locus for $R$. salmoninarum.

Apart from macrophages and melanomacrophages, leukocytes were hardly noticeable in the last stages of the disease. However there was a remarkable presence of plasmacytopoietic foci in the renal and splenic lymphoid tissues. This would support the idea that the fish are able to mount a humoral immune response to the pathogen, in agreement with previous results that demonstrated the presence of Renibacterium salmoninarum-specific antibodies, in the form of immune complexes, in the sera of infected coho salmon (Kaattari et al. 1989) 
In conclusion, our results show that the experimental infection with Renibacterium salmoninarum produces focal necrosis in the renal and splenic haemopoietic tissues. The tissue alterations involved the destruction of the haemopoietic microenvironments, the appearance of epithelioid cells, probably of monocytic origin, and an increase in the number of barrier cells. The barrier cells appeared to be involved in the defence response to the pathogen, but they may also act as a reservoir and proliferation locus for $R$. salmoninarum.

Acknowledgements. We thank Dr Prasad Turaga for conducting the experimental infection. This research was funded in part by the Spanish CYCYT, with grant MAR91-0851. Cooperation between the University of Leon and Oregon State University was funded by grants from the DGICYT (Spanish Ministry of Education and Science) for 'Perfeccionamiento del Profesorado' awarded to B.R. and A.V. E.F. was supported by EC contract AIR1 CT92 0036

\section{LITERATURE CITED}

Álvarez F (1993) Immunobiología de salmônidos. Análisis morfológico de los mecanismos de defensa de Salmo trutta contra la infección por Saprolegnia sp. Estudio del tegumento y los órganos linfoides. PhD thesis, University of León

Álvarez F, Flaño E, López-Fierro P, Razquin B, Villena A (1993) Salmonids barrier cells in disease. VIth Conference of the European Association of Fish Pathologists (EAFP), Brest, p 125

Álvarez F, Razquin B, Villena A, López-Fierro P, Zapata A (1988) Alterations in the peripheral lymphoid organs and differential leukocyte counts in Saprolegnia-infected brown trout, Salmo trutta fario. Vet Immunol Immunopathol 18: $181-193$

Bandín I, Ellis AE, Barja JL, Secombes CJ (1993) Interaction between rainbow trout macrophages and Renibacterium salmoninarum in vitro. Fish Shellfish Immunol 3:25-53

Belding DL, Merril B (1935) A preliminary report upon a hatchery disease of the Salmonidae. Trans Am Fish Soc 65:135-137

Bruno DW (1986) Histopathology of bactenal kidney disease in laboratory infected rainbow trout, Salmo gairdneri Richardson, and Atlantic salmon, Salmo salar L., with reference to naturally infected fish. J Fish Dis 9:523-537

Bruno DW. Munro ALS (1986) Haematological assessment of rainbow trout, Salmo gairdneri Richardson, and Atlantic salmon, Salmo salar L., infected with Renibacterium salmoninarum. J Fish Dis 9:195-204

Castillo A (1991) Ontogenia del sistema inmunitario de la trucha arco iris, Oncorhynchus mykiss. Análisis estructural, inmunocitoquímico y funcional. PhD thesis, University of León

Dannevig BH, Lauve A, Press CMcL, Landsverk $\mathrm{T}$ (1994) Receptor-mediated endocytosis and phagocytosis by rainbow trout head kidney sinusoidal cells. Fish Shellfish Immunol 4:3-18

Earp BJ, Ellis CH, Ordal EJ (1953) Kidney disease in young salmon. Department of Fisheries, Washington, Spec Rep $1: 1-74$
Evenden AJ, Grayson TH, Gilpin ML, Munn CB (1993) Renibacterium salmoninarum and bacterial kidney disease the unfinished jigsaw. A Rev Fish Dis 3:87-104

Fryer JL, Sanders JE (1981) Bacterial kidney disease of salmonid fish. A Rev Microbiol 35:273-298

Hayakawa Y, Harada T, Hatai K, Kubota SS, Bunya T, Hoshiai $\mathrm{G}$ (1989) Histopathology of BKD (bacterial kidney disease) occurred in sea-cultured coho salmon (Oncorhynchus kisutch). Fish Pathol 24:17-21

Kaattari SL, Turaga P, Villena A, Razquin B (1989) Formation of anti-Renbacterium salmoninarum ummune complexes during bacterial kidney disease. International Fish Health Conference, Annapolis, Maryland, USA

Kreipe $H$, Radzun HJ, Rudolph P, Barth J, Hansmann ML, Heidorn K, Parwaresch MR (1988) Multinucleated giant cells generated in vitro. Am J Pathol 130:232-243

Papadimitriou JM, Van Brugen I (1986) Evidence that multinucleate giant cells are examples of mononuclear phagocytic differentiation. J Pathol 148:149-157

Razquin BE, Castillo A, López-Fierro P, Álvarez F, Zapata A Villena AJ (1990) Ontogeny of IgM-producing cells in the lymphoid organs of rainbow trout, Salmo gairdneri Richardson: an immuno- and enzyme-histochemical study. J Fish Biol 36:159-173

Reynolds ES (1963) The use of lead citrate at high $\mathrm{pH}$ as an electron opaque stain in electron microscopy. Stain Technol 35:313-323

Richards RH, Holliman A, Helgason S (1978) Exophiala salmonis infection in Atlantic salmon, Salmo salar L. J Fish Dis 1:357-368

Sami S, Fischer-Scherl T, Hoffmann RW, Pfeil-Putzien C (1992) Immune-complex mediated glomerulonephritis associated with bacterial kidney disease in the rainbow trout (Oncorhynchus mykiss). Vet Pathol 29:169-174

Sanders JE, Fryer JL (1980) Renibacterium salmoninarum gen. nov., the causative agent of bacterial kidney disease in salmonid fishes. Int $J$ syst Bacteriol 30:496-502

Secombes CJ (1985) The in vitro formation of teleast multinucleate giant cells. J Fish Dis 8:461-464

Smith JW (1964) The occurrence and pathology of Dee disease. Department of Agriculture and Fisheries for Scotland, freshwater salmon. Fish Res 34:1-12

Sniezsko SF, Griffin PJ (1955) Kidney disease in brook trout and its treatment. Prog Fish Cult 17:3-13

Weiss L (1991) Barrier cells in the spleen. Immunol Today 12: $24-29$

Weiss L, Geduldig U (1991) Barrier cells: stromal regulation of hematopoiesis and blood cell release in normal and stressed murine bone marrow. Blood 78:975-990

Wolke RE (1975) Pathology of bacterial and fungal disease affecting fish. In: Ribelin WE, Migaki $G$ (eds) The pathology of fishes. University of Wisconsin Press, Madison, p 76-78

Wood EM, Yasutake WT (1956) Histopathology of kidney disease in fish. Am J Pathol 32:845-857

Young CL, Chapman GB (1978) Ultrastructural aspects of the causative agent and renal histopathology of bacterial kidney disease in brook trout (Salvelinus fontinalis). J Fish Res Bd Can 35:1234-1248

Zapata A (1979) Ultrastructural study of the teleost fish kidney. Dev Comp Immunol 3:55-65

Zapata A (1982) Lymphoid organs of teleost fish. III. Splenic lymphoid tissue in Rutilus rutilus and Gobio gobio. Dev Comp Immunol 6:87-94

Manuscript first received: February 20, 1995

Revised version accepted: August 30, 1995 